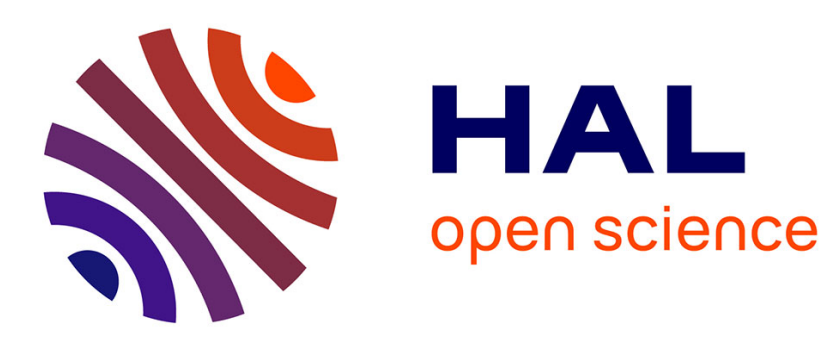

\title{
Saint-Simonism and Utilitarianism: the history of a paradox. Bentham's Defence of Usury under Saint-Amand Bazard's Interpretation
} Michel Bellet

\section{- To cite this version:}

Michel Bellet. Saint-Simonism and Utilitarianism: the history of a paradox. Bentham's Defence of Usury under Saint-Amand Bazard's Interpretation. 2011. halshs-00654847

\author{
HAL Id: halshs-00654847 \\ https://shs.hal.science/halshs-00654847 \\ Preprint submitted on 23 Dec 2011
}

HAL is a multi-disciplinary open access archive for the deposit and dissemination of scientific research documents, whether they are published or not. The documents may come from teaching and research institutions in France or abroad, or from public or private research centers.
L'archive ouverte pluridisciplinaire HAL, est destinée au dépôt et à la diffusion de documents scientifiques de niveau recherche, publiés ou non, émanant des établissements d'enseignement et de recherche français ou étrangers, des laboratoires publics ou privés. 
Saint-Simonism and Utilitarianism: the history of a paradox. Bentham's Defence of Usury under Saint-Amand Bazard's Interpretation

Michel Bellet

Décembre 2011 


\section{GATE Groupe d'Analyse et de Théorie Économique Lyon-St Étienne}

93, chemin des Mouilles 69130 Ecully - France

Tel. +33 (0)4 72866060

Fax $+33(0) 472866090$

6, rue Basse des Rives 42023 Saint-Etienne cedex 02 - France

Tel. +33 (0)4 77421960

Fax. $+33(0) 477421950$

Messagerie électronique / Email : gate@gate.cnrs.fr

Téléchargement / Download : http://www.gate.cnrs.fr - Publications / Working Papers 
Saint-Simonism and Utilitarianism: the history of a paradox.

Bentham's Defence of Usury under Saint-Amand Bazard's Interpretation.

Michel Bellet

\section{Abstract}

This article reveals and studies the connections between Bentham's Defence of Usury (1787) and Saint-Amand Bazard (1791-1832), a founder of Saint-Simonianism. We first traces Bazard's exposure to Bentham through his unknown friendship with Bentham's publisher Etienne Dumont. After introducing in details the Saint-Simonian views on interest and money, we examines the significance of Bazard's translation of Defence of Usury and his shared opposition against usure laws. We explain why the puzzling reference to Benthamite utilitarianism is not fortuitous but appears to justify a common ground between Bentham's utilitarism and Saint-Simonianism. This connection did not survive the July Revolution.

Correspondence may be addressed to Michel Bellet, Professor of Economics, Université de Lyon, Lyon, F69007, France; Université Jean Monnet, Saint-Etienne, F-42000, France; CNRS, GATE Lyon St Etienne, SaintEtienne, F-42000, France; e-mail: michel.bellet@univ-st-etienne.fr.

JEL classification: B1, E4

Keywords: utilitarianism, saint-simonism, interest rate, usury. 
Defence of Usury (1787) is considered one of Bentham's most prominent texts at the turn of the nineteenth century. Since its publication, the pamphlet has been widely analysed and interpreted in the history of political economy. Previous studies dealt with the composition of the text (Stark 1952); the relationship between the conceptions on usury in the works of Smith and Bentham (Hollander 1999, Leloup 2000, Paganelli 2003); Bentham and his brother's innovative entrepreneurial involvement (Pesciarelli 1989, Crimmins 1998); the possible contradictions with his later writings (Sigot 1998); and the principles of British liberalism (Persky 2007). Recent analyses of maximum permitted interest rates have referred to some of Bentham's allegations (Coco, De Meza 2009). In this paper, we do not return to the interpretation of the text itself. Instead, we seek to understand in the context of the SaintSimonian movement the relationship between Bentham (1748-1832) and Saint-Amand Bazard (1791-1832), one of the most important of Saint-Simon's disciples and a founder of Saint-Simonism.

Bazard translated the work into French in 1828. He also included, along with thirteen translator's notes, an interpretative dissertation on interest rates. ${ }^{1}$ Of course, the SaintSimonian movement is known for having elaborated and defended various theories on banks, interest rates, and amortization. However, the connection between Bentham and these SaintSimonian topics has never been evoked. In particular, except in very few cases (De Molinari, $1848)^{2}$, the unusual nature of the relationship between Bazard and Bentham was never clearly discussed, even when Bazard's translation (or his dissertation, notes, and Turgot's text) was directly referenced $(1830)^{3}$. Besides, historians have generally focused on the views of another Saint-Simonian leader, Prosper Enfantin $(1831)^{4}$ and Bazard's work is generally absent from the analyses of Saint-Simonism. ${ }^{5}$

Keeping in mind this first singularity, this paper provides an interpretation to an apparent economic paradox between Saint-Simonism and Utilitarianism. The principal argument of Bentham's text questions and refutes state-imposed caps on interest rates. This type of argument is often identified as a 'liberal' claim in economics. However, Bazard discussed it and found a way to support it. The paradox is therefore the following: why was a social reformer connected to the 'hierarchical socialism' movement in economics interested in Bentham's text, and why did he endorse its principal argument?

\footnotetext{
1. The text is followed by Turgot's Mémoire sur les prêts d'argent (1770), presented by Bazard as another study questioning the laws against usury.

2. In his historical note, liberal French economist de Molinari (1848) contested Reybaud's interpretation (1843) seeing in Bentham the inspiration of an egoistic and calculating approach in economy (even though he regretted that Bazard could not develop all his qualities as an economist due to his "socialist" doctrine).

3. It should be noted that Bentham's works, published in French as Euvres de J. Bentham from 1829 to 1840 based on Dumont's works, took up Bazard's writings in full in the Defence (1830). Quite surprisingly, the unusual nature of this connection is not mentioned.

${ }^{4}$. The book Economie politique et politique is a collection of Enfantin's articles in the Saint-Simonian journal Le Globe, at the peak of the Saint-Simonian School (1830-31). Some other writings should be mentioned (Pereire 1832, Decourdemanche [1831] 1832, Rodrigues 1825ab, 1826ab...). For a selection, see the collection of texts on money and banks translated and presented by Jacoud (2010).

5. For example, Halévy (1908) reviewed the criticism of loan at interest by the Saint-Simonians only through Enfantin and Pereire's writings, ignoring Bazard's translation of Bentham. Yet, Enfantin had a very positive opinion on Bazard's work: "One of our friends translated Bentham's book on usury. He (Bazard) wrote a very good introduction, undoubtedly better than Bentham's writing..." ([1827]1963,185).
} 
To analyse the appropriation of Bentham's work by Saint-Simonism, the article is divided into four sections. In section 1, we trace Bazard's exposure to Bentham through the discovery of an early friendship with Etienne Dumont, the famous publisher and propagator of Bentham's works. In section 2, we outline the foundation of the Saint-Simonian analysis concerning interest and money, which influenced to an extent Bazard's translation and interpretation of the Defence. This detailed introduction to Saint-Simonian economic thought is a requirement for our investigation of the possible connections with Benthamism. Section 3 examines the significance of Bazard's commentary, which both explicitly claims its affinity with the Defence's reasoning and marks its difference from Bentham. The fourth and last section resolves the paradox of an utilitarian strain detected in the Saint-Simonian school of thought. On that regard, Bazard's commentaries correspond to the economic peak of convergence between the two philosophical movements. This leads us to the conclusion that convergence between Saint-Simonism and Bentham was more than a simple coincidence. However, this convergence will later be questioned and eventually failed due to a significant change in historical context (July Revolution of 1830) and the new intellectual requirements implied for Saint-Simonians.

\section{Bazard, Dumont, and Bentham: biographical discoveries}

In this first part, it is referred to new biographical discoveries regarding the relationship between Bazard and Bentham. These biographical details are necessary to understand Bazard's interest in Bentham and his work. This also contributes to explain the lack of knowledge when it comes to the connections between Utilitarianism and Saint-Simonism. The fact that all past and present commentators on Saint-Simonism ${ }^{6}$ have totally ignored Bazard's stay in London and his relationship with Etienne Dumont is critical on that regard. ${ }^{7}$ In previous research, we found out unreleased letters to Dumont in Geneva revealing important elements (Bellet 2011a). These discoveries consolidated already existing assumptions not only about Bazard, but also the entire Saint-Simonian School (Bellet 2011b). These new biographical elements are thus analysed through this wider perspective.

Saint-Amand Bazard's childhood was quite difficult. His father was once rich but ended up ruined after the birth of Saint-Amand, born in Paris of adultary. Saint-Amand Bazard got married very young with Claire Joubert (1813). When he was twenty-three years old, he got involved in a Republican struggle against the return of the Bourbons. On March $30^{\text {th }} 1814$, he distinguished himself in the 'Battle of Paris' by taking gun pieces back from the Cossack, who occupied the capital city with Austrian troops after the fall of Napoleon I. As a result, he was appointed Captain of the National Guard. Later on, he started working as an assistant in the Octroi Service at the Préfecture de la Seine. It seems that in May 1815, Bazard was denounced to the Bourbon government for alleged bonds with Richard-Lenoir's Federates, close to Bonaparte. ${ }^{8}$ He may have been made redundant; whereas it seemed that his role was

\footnotetext{
${ }^{6}$ For example Weil (1896), Charléty (1931), Manuel (1962), Iggers (1972), Carlisle (1988) Picon (2002) or Musso (2004).

${ }^{7}$ On Dumont's role in France and the relationship with Bentham, see Whatmore (2007) and Blamires (2008).

${ }^{8}$ François Richard (1765-1839), a major industrialist in the textile industry, supported Bonaparte's ideas. When the National Guard was created, he was appointed Colonel (January 1814) in the Eighth Legion of Federates (i.e. Lenoir who enlisted 15,000 to 20,000 federate workers), and declared himself in favour of the defence of Paris. On March $31^{\text {st }}$, he occupied Avenue de Vincennes and took over some gun pieces with his Legion. The Royal Order of April $23^{\text {rd }} 1814$ stopped import duties on cotton from England entirely and without compensation. Richard-Lenoir was ruined. He supported the Emperor during the Hundred Days (March-June 1815). He had to sell his properties and accept a pension from his son-in-law.
} 
to prevent the Federates from taking up arms in the Napoleonic period of the Hundred Days. In any case, Bazard probably moved to London from 1814 to 1818 because the Bourbons had returned to power. ${ }^{9}$

Bazard's long stay in London was never evoked in previous works on the Saint-Simonians. This is however crucial, as Bazard met Dumont precisely in London. It is during that first exile that Bazard and Dumont wrote to each other and it is Dumont who introduced Bentham's work to Bazard. When Bazard was in London, Dumont sent him several French translations of books by Bentham. ${ }^{10}$ In other words, Bazard was interested in Bentham long before he converted to Saint-Simonism, and incidentally, long before Saint Simon's first reference to Bentham in $1817 .^{11}$ It is still not clear why or under which conditions Bazard went to London. As a Republican, strongly opposed to the restoration of the Bourbons and to the Bonapartists, Bazard may have felt he had to leave or been forced to.

We think there are three reasons why he chose to go to London and get in touch with Dumont. ${ }^{12}$ First, Bazard was married with Claire Joubert, Pierre-Mathieu Joubert's daughter. Pierre-Mathieu Joubert played an important role. He was a priest who later became a Constitutional Bishop, taking an oath to the Revolution. He was a member of the Constituent Assembly of 1789 and later occupied significant positions. ${ }^{13} \mathrm{He}$ sat in the Convention with Mirabeau, often taking his defence (particularly when Mirabeau died). It is a known fact that Dumont and Mirabeau became close friends when Mirabeau stayed in France. Dumont was a member of Mirabeau's 'workshop' and contributed to his tribune speeches. Therefore Dumont may have helped a relative of one of Mirabeau's friends, that is Bazard himself. Second, Bazard was very close to his brother-in-law, Nicolas Joubert, who followed him in many actions against the Bourbons (creation of secrete societies or lodges, several conspiracies, etc.), which may have strengthened Dumont's intervention. It should also be noted that in August 1790, Joubert, as a member of the Constituent Assembly, presented a report on "the obstacles facing Geneva inhabitants in the Pays de Gex in the transit of grains" (Le moniteur, 1802, 235). That report was about the relationship between Geneva and France. Geneva-born Dumont, who was then in France and was very close to several Convention

\footnotetext{
9. The first four letters to Dumont that we discovered in Geneva were dated: April $23^{\text {rd }} 1814$, August $16^{\text {th }} 1815$, August $10^{\text {th }} 1816$, and May $30^{\text {th }} 1818$. Bazard did live in London (known address) but he might have returned to the continent temporarily, as the alleged 1815 story would imply.

10. Dumont fled to London in June 1793, and did not return to Geneva until May 1815 (Conway, 1988), to participate in the creation of a new Code, after the return of the Republic of Geneva. He stayed there until April 1818 and went back to London after a short stay in Paris in May 1818 (Conway1989). Bazard's first letter to Dumont in 1814 was thus sent to an address in London. It shows that they had met in person. The two other letters (1815 and 1816) were sent to an address in Geneva. The address of the last one was lost, due to that first exile (1818).

11. This first reference is in the third book of L'Industrie, about the Plan of Parliamentary Reform (1817). It was actually formulated by Auguste Comte, who wrote the third and fourth books. Comte probably didn't read Bentham's book directly. We think that he very likely used Say's report published in 1817 in Revue Encyclopédique. On this subject, see Bellet (2009).

12. The only known fact is that Dumont's nephew and François d'Ivernois (1757-1842) acted as intermediaries. François d'Ivernois, a citizen of Geneva who then acquired British nationality as Sir Francis d'Ivernois, knew Dumont and Bentham very well (as the numerous letters in the Correspondence of Jeremy Bentham show). Dumont's nephew was the son of Dumont's sister, Jacob-David Duval (not Jacob-Louis Duval, his grand nephew, who published the posthumous edition (1832) of Dumont's Souvenirs sur Mirabeau.

13. Pierre-Mathieu Joubert (1745-1815) resigned from his ecclesiastical functions and got married in 1793 . He then was appointed president of the Seine Département managing entity. In October 1798, he became the manager of the Octroi service in Paris. In 1800, he was appointed Préfet at the Préfecture du Nord. In 1801 he was dismissed by the Emperor, but he obtained a position as an adviser at the Préfecture in Paris, which he occupied until he died. The Restoration government did not dare dismissing him for fear that he might refuse to resign. His son Nicolas also worked at the Octroi. His father may have favoured the recruitment of his son and son-in-law.
} 
members, was probably interested in that report, which resulted in the "Decree on the transit of grains for Geneva inhabitants in the Pays de Gex" (August 29 ${ }^{\text {th }} 1790$ ). ${ }^{14}$ In that case, Joubert and Dumont could have met directly, which would have made Bazard's place of exile easier to find for Dumont. Lastly, two other influential persons may have played a part in Bazard's exile: Lafayette, ${ }^{15}$ to whom Bazard became very close later on, and alternatively or simultaneously, M. R. de Voyer d'Argenson. ${ }^{16}$

After May $30^{\text {th }} 1818$, Bazard is likely to have returned to France. Indeed, in September 1818, Bazard created a kind of Republican-oriented Masonic lodge, The Friends of Truth, with Flotard, Buchez ${ }^{17}$, and his brother-in-law Joubert. In other words, he did not give up on direct, insurrectional Republican activities. For instance, from December $1^{\text {st }} 1819$ to April $30^{\text {th }}$ 1820, he participated in the third version of a Republican-oriented journal, L'Aristarque français. He published eleven identifiable articles in 1820, as "St A. B...d" or "St. A.B.". ${ }^{18}$ In August 1820, the Logde of the Friends of Truth had grown even joined a military conspiracy against the Bourbons (sometimes referred to as the "Bazar de Paris"). This conspiracy failed due to betrayal. ${ }^{19}$ Some of the conspirators (Joubert and Dugied) fled to Italy. They were connected to the carbonari before returning to Paris. However, what Bazard did right after the failed conspiracy remains obscure. The only known fact is that he created a French society of carbonari with Buchez, Dugied, Joubert, Flotard, and a few others in February 1821. He chaired the society for a few months and was later replaced by Lafayette. Buchez, who was head of Haute Vente Masonic Lodge in Eastern France, gave Bazard and Joubert the mission to check the feasibility of a conspiracy in that region (Mulhouse, Neuf-Brisach, Colmar,

14. The contents of this Decree can be found in Duvergier (1834). It should be noted that Duvergier, an important early nineteenth century lawyer, was interested in Bentham in his Saint-Simonian period (particularly in 1825, see infra).

15. The famous Marquis Du Motier de La Fayette (1757-1834) also known as Lafayette, played a crucial role under the Restoration. It should be noted that he and Bentham wrote to each other as soon as September 1821 (letter 2804) and kept doing so later on: letter 2854 in February 1822, letter 3091 in April 1824, letter 3222 in October 1825, 3301 in January 1827, 3343 in May 1827, and 3360 in September 1827 (respectively Convay 1994, Fuller 2000 and O'Sullivan, Fuller 2006). It is a known fact that Bazard acted as an intermediary between the Saint-Simonians and Lafayette in the Revolution of 1830 to encourage him to take power. Their attempt eventually failed.

${ }^{16}$. Both were friends. Marc-René de Voyer de Paulmy d'Argenson (1771-1842) was a Préfet at the Deux-Néthes from 1809 to 1813 . He was also General Wilson's agent, and represented Belfort during the Hundred Days, and was elected in Haut-Rhin and other Départements almost continuously from 1816 to 1833 , as an opponent to Bourbons. As an industrialist, he supported many militaries who broke away with their carriers after participating in conspiracies. He had an important relationship with the French carbonari and Buonarroti (as a member of Vente Suprême). He stayed in London from June to late August 1822, maybe after he was accused in the investigation on the Belfort conspiracy and in his reactions at General Berton's trial in Poitiers after the Saumur-Thouars conspiracy in February 1822. Bentham evoked the name of d'Argenson for the first time on September $30^{\text {th }} 1817$ (letter 2417 in Conway 1989), as the addressee of his book Codification Papers in Paris (with other addressees including Say, Comte, Dunoyer, Romilly, etc.), and in November 1821, through Say, as a distributor of Bentham's brochures (letter 2819 in Conway 1994). He wrote to Bentham from London on June $9^{\text {th }} 1822$ to accept his invitation (letter 2892 in Fuller 2000); on June $12^{\text {th }} 1822$, they planned another meeting "before his departure" (letter 2903, ibid). On August $24^{\text {th }}$, he wrote from London to announce that he postponed his departure because he was ill and wanted to go back home as soon as possible (letter 2914, ibid); from Paris, he had a close relationship with Bentham (letters dated January $2^{\text {nd }}$ and January $22^{\text {nd }} 1823: 2939$ and 2943 , ibid), as d'Argenson acted as a very active intermediary between Bentham and many people in Paris. However, Lafayette and d'Argenson seem to have had significant relationships with Bazard after 1818. Often elected deputy from 1815 to 1833 , d'Argenson will correspond with the Saint-Simonian newspaper the Globe in 1830.

17 Flotard worked at the Octroi with Bazard. Philippe Buchez (1796-1865) was a medical student; after the masonic and carbonaro episode, he became a saint-simonian disciple in 1825-1831.

${ }^{18}$ The BnF collection (Paris) is not complete.

${ }^{19}$ The Chambre des Pairs instituted as a Court of Justice took a relatively moderate decision (July $\left.16^{\text {th }} 1821\right)$, however they were sentenced to death in absentia. D'Argenson and Bazard were not involved. Lafayette was accused at the Chamber of Deputies. 
Belfort, Strasbourg, etc.). Bazard took part in the failed Belfort conspiracy in December 1821 and January 1822 with Lafayette. Bazard and another conspirator saved Lafayette by warning him; he probably had to go underground, since he was involved in the conspiracy. ${ }^{20}$ Bazard possibly stayed in various places before going to London again, as showed by a police statement and the letter he wrote in 1824. Although the historiography does not mention this second exile to London, it is likely that Bazard and Dumont got in touch again, hence the work on Bentham. It is hard to determine how long the second stay was, as the in absentias were interpreted differently according to the cases tried against Bazard, and the sword of Damocles was hanging over him. ${ }^{21}$

Bazard's study of Bentham's writings resulted in two relatively famous articles published in 1826 in the Revue Encyclopédique, under the name of "Saint-Amand", probably due to his underground activities. In view of their content, both articles were probably written before Bazard converted to Saint-Simonism, and published later. Bazard first read Saint-Simon's writings in 1825 thanks to Cerclet. ${ }^{22}$ He adopted the doctrine progressively, until he signed his first article in Le Producteur, in November 1825. He became one of the major contributors to the journal ( 8 articles published, including a call for the constitution of a veritable doctrine). He then strongly contributed to L'Exposition de la doctrine $\left(1930^{23}\right)$, a seminal text of the Saint-Simonians. Other Saint-Simonians added to this text, incidentally including several passages on Bentham, inspired by Bazard's conferences given in 1929 and $1930 .^{24}$ Bazard was appointed "Supreme Father" on December $31^{\text {st }} 1829$ and was, along with Enfantin, the leader of the movement. During the Revolution of 1830 , on July $31^{\text {st }}$ he became the emissary of the Saint-Simonians trying to convince Lafayette to take power, unsuccessfully. As soon as November 1831, he and Enfantin disagreed on a growing number of points. On November $11^{\text {th }} 1831$, Bazard resigned from his leading position, trying in vain to gather the SaintSimonians around him, and then retired in Courtry, where he died in July 1832.

The translation and commentary of the Defence in 1828 were part of a wider process. The translation and commentary of the Defence in 1828 were part of a wider historical and

\footnotetext{
${ }^{20}$. He was sentenced to death in absentia and there was a permanent threat until the prescription period came to an end (probably with a royal act of amnesty in May 1825).

${ }^{21}$. Indeed, several trials on conspiracies in Eastern France were held. General Berton was sentenced to death after the failed attack by La Charbonnerie in Thouars and Saumur, in February 1822. At the Belfort conspiracy trial on August $13^{\text {th }} 1822$, all defendants but four were acquitted; in absentias Bazard et Joubert were ignored. At the jury-less Colmar Cour d'assises on September $30^{\text {th }} 1822$, seven defendants were sentenced to death and one was sentenced to five years in prison but the judgement was stayed, leaving the trial opened for all defendants in absentia. The Tribunal did not know their names, except for Bazard and Joubert (whose name were very famous). Besides, after the bomb conspiracy in July 1822 (known as the Caron and Roger conspiracy), the defendants were sentenced to death by the War Council on September $18^{\text {th }} 1822$. Caron was executed. In the same case, the sentence was commuted by the Court to 20 years of hard labour with three public notices on the doors of the court-rooms. At the Strasbourg War Council on August $22^{\text {nd }} 1822$, three military conspirators from Metz and Strasbourg were sentenced to short prison terms. In other parts of the territory, four sergeants from La Rochelle were trialled and executed on September $21^{\text {st }} 1822$. In such a context, one can understand that some people were inclined to underground activities and exile (for example, d'Argenson in London).

22. Auguste Cerclet was a journalist. He was the editor in chief of the major Saint-Simonian journal Le Producteur from its creation after Saint Simon's death (May 1825) to late March 1826. Later he was the editor of Le National and Le Journal des débats, two liberal opposition newspapers.

${ }^{23}$ Enfantin, Prosper, and Carnot, Hippolyte, and Fournel, Henri, and Duveyrier Charles (1830). See in English Iggers (1972).

${ }^{24}$. However, these passages cannot be attributed to Bazard with certainty, as it was a collective work (the authors of articles were not necessarily those who gave the conferences). Besides, other Saint Simonians worked on Bentham's writings (Duvergier, Enfantin) or were connected to him directly (Rodrigues, Rey, etc.). The major passages about Bentham $\left(8^{\text {th }}\right.$ and $12^{\text {th }}$ sessions) were attributed to Enfantin, except for the $7^{\text {th }}$ and $9^{\text {th }}$ session, where Bazard was more involved, following the Saint-Simonian historiography. See Bellet (2011b) for more information on the relationship with Bentham.
} 
intellectual process. It was the logical outcome of an attentive and long-lasting study of Benthamite utilitarianism: his close relationship with Dumont and the five letters written between 1814 and 1824 clearly account for this process. Besides, Bazard was looking for a new, non-insurectional approach after having witnessed the return of the Bourbons and the victory of the monarchist all over Europe. Having been involved in armed conspiracies, he now had to cope with trials and convictions. Benthamian utilitarianism was a universal and reformist doctrine from which he could borrow, without having to convert to Benthamism. As mentioned previously Bazard's interest in Bentham was actually related to his exiles in London (1814-1816, 1824) and Dumont's influence. In 1814, Bazard thanked Dumont for his "gift" in a letter he wrote after they had met, indicating that he would "read the thoughts of his beautiful genius" and "learn". He also suggested they meet at his place. Dumont's gift is not known, but it was probably Bentham's Traité des peines et des récompenses, published in $1811^{25}$ and evoked later in another letter. In the 1815 letter, Bazard directly referred to the Traité de législation, published in $1802 .^{26}$ After appraising the book ${ }^{27}$ and the bonds with Bentham, he even gave some advice, approving Dumont's idea for the French title, "Logique de Législation", which eventually was not retained. Furthermore, he made some critical remarks on specific terms precising he had already done so about Traité des peines et des récompenses. Finally, he evoked his great financial difficulties (paying off a debt through Dumont's nephew), along with his health and his wish to give Dumont a manuscript about "finances, French public debt, public credit, and the debt system." The 1816 letter was also sent from London. It is a very short letter where Bazard mentions that he is still studying Dumont's book, feels ill, and cannot leave London yet. It can clearly be inferred from the letters written during the first exile (1814-1816) in London that Bazard read Bentham's work and had a close relationship with Dumont. However, they do not contain a proper analysis of the Utilitarian doctrine.

This is not the case for the 1824 letter sent in the second period of exile. At that time, Dumont was staying in London. Bazard's 1824 letter mentions Dumont's third gift, Bentham's Treatise on Judicial Evidence, appraises the qualities of the book, which contains "cases that resembled his own experience" and a "selection of arguments" that could have proven him right in front of any injustice. Bazard evoked his personal situation again, ${ }^{28}$ and asked for Dumont's help to write a defence, probably referring to his 1822 sentence in absentia. In 1824, Bazard read three additional books by Bentham, which had been translated by Dumont. He surely took advantage of his two stays in London to further study Bentham's work. During Bentham's last stay in France, in November 1825, Bazard also met the English publicist very discreetly in Lafayette's La Grange castel. ${ }^{29}$ As we mentioned before, two articles on Bentham's work published in 1826 were written before the Defence was translated, and before the dissertation on the Defence was written. The first one (1826a), "Notice sur les ouvrages de Jérémie Bentham" (Note on Jeremy Bentham's books) contains a list of twentytwo texts by Bentham published in English, along with the four books edited by Dumont in

\footnotetext{
25. A part of the manuscript Manual of Political Economy written in 1795 was translated and introduced in chap. IV, with title: Des Encouragemens par rapport à l'Industrie et au Commerce.

26. Traités de législation civile et pénale (1802) edited in three volumes by Dumont from Bentham's writings. A part of Bentham's famous text (1789), An Introduction to the Principles of Morals and Legislation, is found here, with changes in the organization of the book and special translation by Etienne Dumont.

27. He considered it was "based on solid background information, well-organized, accurately distributed, nicely executed, clearly stated with a simple, pure, easy, and natural method", etc.

28 "You are the only one who can save me. I hate to think of what comes next."

29. See O'Sullivan, Fuller 2006 (letter 3222 from Bentham to Lafayette and letter 3228 from Bentham to Dumont).
} 
French, with brief, generally very positive commentaries on the author's work. The Defence is one of them; and the remark reads:

The book might have had a different title. Bentham's critique of Adam Smith advocates free trade in money in response to further restrictions on interest rates by the government. Therefore, this is not an apology of usury, but the proof that so-called usury should no longer be considered as an offence. Bentham's dissertation is a masterpiece, both in form and content. (1826a:300)

Bazard continued his work in the same Revue encyclopédique. In September 1826, he reviewed sixteen pages of Bentham's Papers relative to codification and public instruction published in London in 1817..$^{30}$ In this review, Bazard accurately describes the systems of law in Bentham's book and compares it with Von Savigny's German historical school concerning codification. As opposed to the German School, he argues that every system makes use of abstraction, even those built exclusively upon historical facts. He also supports the Benthamite project of proposing a methodological and permanent body of rules to understand history. Diversity and historical changes are not explained by absolute differences but by the many shapes a same body can adopt. Nevertheless, Bazard thought that the debate was still open between the two schools. ${ }^{31}$

From 1814 onwards, Bazard studied intensively the Benthamite system, admiring a theory whose attempt was to provide a general system of interpretation. The new biographical elements presented show that the aforementioned "paradox" is not anecdotic and is worth investigating. The translation and commentary of the Defence in 1828, while Bazard was a member of the Saint-Simonians, is a critical achievement of a long process aimed at integrating Bentham into the Saint-Simonian approach.

\section{The Saint-Simonians views on bank, credit, money, and interest}

Bentham's initial text (1787), consisting of twelve letters to a friend (George Wilson) and one to Adam Smith, was translated into French twice before Bazard's translation: once in 1790, possibly by Mirabeau or more probably one of Mirabeau's friends (Clavière), and in 1790 by Etienne Delessert. ${ }^{32}$ Some extracts, or more precisely an introduction to the Defence, were later published in French by Dumont in the Geneva journal Bibliothèque Universelle in $1817 .^{33}$ When Bazard published his own edition of the book containing his dissertation, he

\footnotetext{
30. This collection was never translated into French by Dumont.

31. At that time Bazard seemed close to Pellegrino Rossi's position. Rossi (1787-1848) was a famous jurist who attempted to connect the two schools before becoming a clear opponent to Benthamite utilitarianism. Later, the evolutionary laws hypothesis (Exposition de la Doctrine, 1830) may have been for Bazard a way to reconcile general unity with historical diversity, as in the case of the historical tendency of the interest rate to fall.

32. It should be noted that Etienne Delessert (1735-1816) was Benjamin Delessert's father (1773-1847), a banker who later financed the publication of L'Industrie (1816-17) initiated by Saint-Simon (with participations by young Auguste Comte, among others). The banker met Bentham in 1792 and 1802, and they started a correspondence. In 1802, he was appointed Regent of the Banque de France.

33. Dumont's publication was not exactly an extract. Indeed, as Dumont wrote: "instead of following the book chapter by chapter, we will just provide an overall presentation" $(1817,3)$. The book was therefore a nine-page summary. Stark's recent edition (1952) is the onyx one introducing the unpublished Preface and Postscript to the second edition. In the Preface, Bentham evoked "an intelligent Frenchman" who published a French translation "he had made for his own amusement", with no further description (probably Delessert, whom Bentham did not clearly identify). Bentham evoked the French translations again in a letter he wrote in 1820, but never Bazard's (Letter 2692, 1826, in O’Sullivan, Fuller 2006).
} 
had already rallied to the Saint-Simonians. However, Bazard's edition is much more than a follow-up to previous works: it is really an attempt to integrate Bentham's thought into a Saint-Simonian context, and therefore a critical expression of the ties between SaintSimonism and Benthamite utilitarianism in economics.

To understand this achievement and the connections when it comes to the law on usury, the Saint-Simonian views on interest and banking should be introduced in details. The period over which Bazard wrote his dissertation corresponds to the time when the Saint-Simonians doctrine on interest rate was being built. ${ }^{34}$ Bazard actually integrated the outlines by Rodrigues, Allier, and above all Enfantin in his texts published before 1828 in Le Producteur (1825 and 1826), the first major Saint-Simonian journal. ${ }^{35}$ These are the early stages of SaintSimonian economic thought. Bazard inherited an approach that can be described in three different but related ways: first as a theory of interest integrated into a theory of labour and productive class; second as a theory of interest related to a fragmented theory on money; third as a theory of interest deeply related to an approach of bank organisation. These three elements help understand the Saint-Simonian position on maximum permitted interest rates.

\section{Interest and the productive class}

Usury and interest rates are fundamentally dependent on a definition of labour and of its role. For the Saint-Simonians, only labour from workers creates wealth. Saint-Simon and the SaintSimonians make a separation of the social structure in two classes. First the workers, in a broad sense at the time, i.e. including industrialists (and farmers, manufacturers, traders, and bankers), scientists, artists (with ethicists, and priests). ${ }^{36}$ Second the idle, earning a living not based on their labour, i.e. all non-working owners (capitalists who did not participate in production, persons of independent means, etc). If Saint-Simon hesitated and improved the approach, considering many intermediary situations (the role of 'intermediary classes' such as jurists and metaphysicians, the role of a 'middle power', etc.), this division was however confirmed and systematised by the Saint-Simonians. The questions of labour and of the "constitution of property" were critical also because property had been historically associated to labour only progressively. Indeed, the distinction between both classes was also related to "historic evolutionism", which depended on the physiologic analogy of the social structure or system. The reference to "perfectibility", borrowed from Condorcet, was transformed by Saint-Simon into a global march of civilization, i.e. a transition between "regimes" followed by a transition from "a feudal and theological system" to "an industrial and scientific system" with critical periods and periods of reconstruction. The disciples of Saint Simon maintained

\footnotetext{
${ }^{34}$. The Saint-Simonians meant to "develop a positive theory on credit and circulation", as Rodrigues wrote $(1826 \mathrm{a}, 7)$.

35. The theory on interest was later developed in 1829-32, in the Saint-Simonian journal Le Globe with articles by Pereire (1832), Rodrigues (1831), Decourdemanche ([1831] 1832), and Enfantin's famous articles, later gathered in the brochure entitled Economie politique et politique in 1831 and 1832). The theory was also developed in the $7^{\text {th }}$ session of L'Exposition de la Doctrine (1831-32) entitled "Constitution of property. Organisation of banks." That second phase is globally more radical: a call to the elimination of money, not only through precious metals (Pereire 1832, as monetary signs perpetuate distrust and the struggle between suppliers and demanders), a questioning of the Banque de France monopoly, and a call to the constitution of "free banks" (Decourdemanche [1831] 1832). However, even in writings that were more influenced by the working class (for example C. Béranger in 1832), no demand of a legal interest rate was ever formulated.

36. The trilogy between industry, science, and Fine Arts actually matches the major human functions: interests, ideas, and feelings, fundamentally depending on the Saint-Simonian physiological metaphor of "organization", of social body. That physiology decisively replaced the former framework of a physiology of "sensation" and "transformed sensation".
} 
the analysis in terms of historical law describing movements from periods of transition (or "critical" periods) to "organic" periods ${ }^{37}$. This process should have resulted in the complete transition of property to workers ${ }^{38}$ with every historic period improving the transition. It can be noted that from the creation of the Saint-Simonian journal Le Producteur to Bazard's translation and analysis of usury, the authors kept elaborating articles based on that conceptual framework, in particular through Rodrigues and Enfantin's pieces in 1825 and several contributions in 1826.

For the Saint-Simonians labour is at the basis of production, and the products of labour can be presented in two funds: the consumption fund (living expenses, clothes, science and Fine Arts, etc.) and the production fund (tools, machines, raw materials, land, production animals). Both funds tend to balance each other out and grow in the historical process described by the Saint-Simonians in 1825-26. However, two aspects need to be taken into consideration in a study on the Saint-Simonians. The historical process does tend to a growth of both funds: there is first the general approach of accumulation of capital, and second a law improving the lot of the most numerous, planet-wide ("complete exploitation of the world"). In other words, the rate of accumulation of capital in an industrial society - which was not yet a reality - would tend to decrease (Rodrigues 1825b, 198-99). ${ }^{39}$ Interest rate, fundamentally related to the rate of accumulation of capital, must therefore tend to decrease in a long-term historical process. However, the very long-term vision involving the relationship between man and nature is not sufficient to explain the development of interest rate: an institutional framework is also necessary (i.e. social organisation or social combination, in the words of the Saint-Simonians).

Indeed, Saint-Simonians defines interest as nothing else but a rent related to capital loan, just as farm rent was related to land lending, i.e. a situation where the owners were not or no longer the producers (Enfantin 1825). As long as both production instruments (land and capital) were owned by the idle, the monopoly or virtual monopoly of the idle allowed for the defence of payments that were unfavourable to the working class (with high farm rent and interest rates). However, the institutional process of property would lead to a progressive transfer of property to workers, ${ }^{40}$ in historical phases, and particularly in the industrial society. For Saint-Simonians, the progressive transfer depends on the capacity and trust in the

\footnotetext{
37. These expressions appeared after 1828 in L'Exposition de la Doctrine (1829, first published in 1830) but the notion was already present earlier (Enfantin, 1826).

38. A law of species (i.e. the social structure) at work on the limit (in the mathematical sense, as claimed by the Saint-Simonians).

39. The Saint-Simonians sometimes used this notion to define the variation rate of accumulation, and sometimes to designate the ratio between accumulation and wealth at a given period of time.

40 . It is too often forgotten that in the first phase of the Saint Simonian theory, the "wage" category included all the working population earning an income (not just strictly 'workers'). In other words, interest and tenant farming existed through rented production tools. If the property of these means by non-producers led to taking a part of work products for the producer, 'spoliation' or 'destruction of capital' was implied. So the social trend integrated an increase of 'wages' (in the Saint Simonian sense) that could indeed be observed through the raise in the standard of living in Enfantin's time. Thus, Malthus or Sismondi's conception of wage was very different from Enfantin's. If the instruments were owned by the producers, the profit and rent (even at a high level) were wages. 'Capitalists' were capital owners who did not work or were retired (not industrialists): they only had rights on production instruments they owned from their past activities, but no right on work products in which they did not participate "under the pretext that they had provided those work instruments" (1826a: 101); 'owners' were landlords who did not work or were retired (not farmers). They had no right on the new work related to that production instrument. That model of analysis changed when riots started causing problems in terms of payment for workers and craftsmen (crisis, and in 1831 Canuts revolt and others). The situation started changing when the 'working class' was seen as distinct component among producers (Rouen 1826, 308-312 in particular). The notion of 'wage' became ambivalent and very difficult to analyse: special status for workers who could not generate loss, or associations... The notion of exploitation according to the Saint-Simonians also became ambivalent.
} 
productive ability of workers. Thus, interest rate and farm rent rate would tend to decrease, in a constant and growing manner, until they would be eliminated. However, two trends must be distinguished within interest rate: strict interest rate and risk premium. The former corresponds to a rent that must tend towards elimination. The latter takes into account the reputation and solvency of the working borrower. Risk premium, ${ }^{41}$ also called solvency bonus, had to decrease with the development of a mutualised and hierarchical banking system based on the cooperation between workers, but it would not be eliminated.

\section{Interest and money}

The Saint-Simonian appreciations were not only limited to these kinds of practical considerations, which would otherwise make them comparable to the ideas of banking or finance specialists. ${ }^{42}$ They were an attempt to draw on a more general conception of money and interest. For that matter, John Law can be considered as the reference author for the SaintSimonians ${ }^{43}$ combined with the influences of Smith, Say, and Ricardo's conceptions on money. "Law's system" was quite widely attacked at the time, at least its consequences. ${ }^{44}$ Still, Rodrigues (1826ab) and Enfantin (1826g) defended Law on three aspects of his thought, used to support their own conceptual framework.

First, according to them, Law was more than an "ingenious and bold speculator" (1826a, 7). If his financial scheme eventually failed, his work was positive, particularly its impact on the depreciation of the numéraire, which induced a transfer from the idle to the producers. His work therefore contributed to the questioning of idleness itself, through his defense of a transfer towards industrialists and his critique of the high cost of money, seen as a sign of misery $(1826 \mathrm{~g}, 220$, where Enfantin quoted a letter by Law).

Second, for the Saint Simonians, Law meant to replace metal money by fiat money. Indeed, he no longer secured money on precious metal but on land, and beyond, on paper bank notes. The Saint-Simonians supported that conception, repeatedly referring to a sentence by Ricardo ([1817] 1819)- especially Enfantin (1826a, 19 and 118) - taken from Chapter 27 of On the Principles of Political Economy and Taxation ("On Currency and Banks"): "A

\footnotetext{
41. That distinction between interest rates strictly speaking and risk premium could be found in Say (1803) and Storch (1823). In Bentham (1787), particularly in Letter 13 on creative industry against Smith, interest rate was proportional to investment risk; therefore, it was higher in the funding of 'men with projects'. However, in Enfantin, risk premium could be decreased (though never eliminated) by the effects of bank mutualisation. See below on this question.

42. The strong influence of the Saint-Simonians in banking (particularly the creation of Crédit Mobilier in 1852 by the Pereire brothers) tended to imply that kind of analysis, except in Sraffa (1929), providing a much more generic sense to practical Saint-Simonism.

43. Enfantin may not have read Law's determining book (1705 in 1790). Law's letter mentioned by Enfantin was actually in Marmont du Hautchamp's books (1739). Laffitte's very successful book (1824) was mentioned twice, though it focused on public credit. Rodrigues (1826a), on the other hand, referred quite precisely to Law's Considérations sur le numéraire et le commerce and Mémoires et Lettres sur les banques (probably the French translation, in 1790). He also criticized the note on Law by Thiers in 1826, and referred to Forbonnais (1758) on the discredit of the notion of 'plan' or 'system', consequently to Law's failure (p. 18-19).

${ }^{44}$. See Say ([1803] 2006 first edition, until the 1826 fifth edition in Say's time, which the Saint Simonians may have read, who was very critical (except for the first stages of the system) on paper money (502-508) and the alleged effects on interest rate (764-773). See also Storch (1823, volume 2, Book 6, Chapter 14, 401 and note 16, “Law's system”). See also Bentham's opinion on 'Law's system' in Traité des peines et des récompenses (1811) edited in French by Dumont, which Bazard read: "when the government itself intervenes with operations which effects are as important as sudden in view of a rapid increase of metal or cash monetary capital, it is being irrelevant and careless, it ruins its subjects, and its imaginary wealth becomes the instrument of its own destruction" (Book 4, Chapter 13, Des moyens d'accroissement de la richesse (Means of accumulation of wealth), p. 339. That book was actually part of the manuscript of Manuel d'économie politique recomposed by Dumont ; this sentence does not appear in Stark's version of the Manual (1952, vol. I).
} 
currency is in its most perfect state when it consists wholly of paper money". However, the quote was incomplete as the end of Ricardo's sentence writes: “...but of paper money of an equal value with the gold which it professes to represent." 45 The Saint-Simonians believed that the total elimination of metal money was feasible (Enfantin 1826a, 124). It would however result from the achievement of management economies, in a general theory of product movement (this last word embodying a variety of stages described below) and thanks to successive movement agents. It would therefore not come from the characteristics of managed money per se. As opposed to Law, the Saint-Simonians did contest the regulating role of metal money since in their views the crises would happen anyway (Enfantin 1826d). More precisely, they anticipated the elimination of that type of money. Money was integrated in a historical sequence of continuous improvement in the movement of products: from 'exchanges' (goods for goods), to 'sales' (through precious metal money), and then 'promises' (through paper money, i.e. banknotes, bills of exchange, etc.). The SaintSimonians placed banknotes and bills of exchange in the continuity of money, therefore adopting Say's early opinion (Second book of the Traité, entitled "On moneys"). ${ }^{46}$ Yet, the Saint-Simonians did not agree with Say's reluctance on paper money. It can be argued that the elaboration of a deeper theory on money was hindered by the fact that the Saint-Simonians were trying to connect too different views. They supported a conception of money as an agent of movement, inspired by Say, but which they integrated in a theory consisting in changing the means of circulation of products to favour a transfer from idleness to work. The conception of money was closely related to a general theory of circulation and the speed of circulation between funds (products moving from one hand to another), with the associated transmission of property rights. However, that conception did not result in a theory of liquidity.

Third, according to the Saint-Simonians, Law defended a decrease in interest rate from when the money was issued. They approved the decrease but as we said before, thought that Law had misinterpreted it as being the consequence of the development of paper money. Law, they said, hadn't "worked deep enough on the nature of banknotes; he did not know in what conditions banknotes were issued" $(1826 \mathrm{a}, 8)$. To Enfantin, Law believed that interest rate could be decreased in the proportion of the banknote issue for his territorial bank project, which he said was wrong. ${ }^{47}$ Interest rate was a variable depending on the general economic conditions. According to the Saint-Simonians, the belief that the origin of prosperity was the abundance of money (metal and paper) automatically led to an almost unlimited increase in the numeraire. ${ }^{48}$ The Saint-Simonians therefore considered that a limit in the amount of

\footnotetext{
45. Practically speaking, the monetary and financial management of W. Pitt (1759-1806), the British Chancellor of the Exchequer and later Prime Minister from 1782 to 1801, was also evoked and defended, as was the financial experience of Abbé Terray, Louis XV and Louis XVI's Minister of Finance (1770 to 1774). That defence was mostly based on questioning metal money (Enfantin, 1826d for example). Experiences of bank development often quoted are Pinto, Laffitte, Laborde and Necker one's (for instance Rodrigues, 1825a, Enfantin 1826i). About Pinto's experience, see Cardoso 2005.

46. The distinction between money and banknotes did not appear either in Say's critical notes integrated in Storch's book (1823), which the Saint Simonians read. Say made this distinction later on (1829): he considered that, as representative signs, banknotes did not have a value of their own.

${ }^{47}$. Law wished a $2 \%$ interest rate.

48. Law actually defended the idea that paper money could, contrary to metal money, be as important as the "quantity of things". With paper money, numeraire can be provided to anyone requesting it, within the limits of the value of things, i.e. the production price. Therefore, the notion of merchandise money had not disappeared. The Saint-Simonians considered money as one of the movement agents revealing a balance of power, meaning a state of organisation given by the relationship between the idle and the working population, more than the value of things. The theory of money was thus integrated in a more general theory of fluidity and the rate of flows, here the movement of products (advances to producers by non producers) fundamentally explaining economic crises ("encombrement" in case of non-fluidity).
} 
money issued was necessary, even though there was no need to have a determined proportion between fixed capital and circulating capital. This was shown clearly in the contestation of Fazy's book, a famous work at the time (Enfantin 1826e or 1826c, 370), ${ }^{49}$ or the absolute refusal to have a "dead, inactive capital in bank coffers" $(1826 i, 61)$. Enfantin was radically opposed to rely on a quantity of tied up capital in order to secure numeraire. He also rejected the idea that banknotes should be based on expected repayment in sight. Two features related to the organisation of production defined the only other limits to issuing banknotes for the Saint-Simonians. The first one is the relationship between the amount of work provided by workers (in the Saint-Simonian sense) and capital owned by the idle (capitalists and owners). The second feature corresponds to the facility of transferring capital to workers, meaning, in the current historic phase, the unquestioned trust related to the promise contained in banknotes, bills of exchange, and credit, if ensured by a certain type of bank organization. Under such conditions, issuing banknotes could decrease interest rate, and that decrease could have a real effect on the economy: here, a faster transfer from idleness to work.

In conclusion, the Saint-Simonians did not regard interest rate as a monetary variable. Contrary to Law (Murphy 1997) or Say (Tiran 2003), the Saint-Simonians did not use the idea of money demand, and did not consider that interest depended on 'lendable capital' ${ }^{50}$ The part of products that was indeed taken from producers (but not from their profit in the Ricardian sense) could be limited through the developed credit, resulting in a decrease of interest rate. The Saint-Simonians did start to develop a monetary and credit theory, its unachievment being due to the gap between the defence of a critical expansion of money to paper money (as well as credit instruments) ${ }^{51}$ and a conception of money almost limited to a means of transport of capital. Credit did not create anything; all it did was distributing capital: it "delivered the products of the future to work. The effects on work should be felt." (Enfantin 1826k, 150-151).

\section{Interest and bank organisation}

The Saint-Simonians were also Law's heirs in the importance given to credit, with the new and generalised role of confidence (fiat money). But they never referred to a 'credit theory of money' - Thornton for instance was never mentioned.$-^{52}$ If the importance of credit was still far from its maximum development according to Enfantin, it was however related to a clearly claimed institutional structuration of banks. Such a banking and financial architecture was quite different from Law's conception. It followed three critical features:

First, banks were not just intermediaries. The Saint-Simonians gave them a particular status, ${ }^{53}$ with an industrial dimension at stake. Indeed, their purpose was to make

\footnotetext{
49. Fazy (1794-1878) was a lawyer and a politician in Geneva. Fazy created Le Journal de Genève in January 1826. He was opposed to Louis-Philippe while in France. In 1818, he wrote one of the first reports questioning the privilege of the Banque de France. In 1826, he wrote a widely distributed book on the dangers of credit, based on his 1818 assumptions, against Laffitte's book (1824). He later created several banks (Banque de Genève and Caisse hypothécaire).

50. Say (in editions 2-6, T1, 773) defended the idea that interest dependent on the relationship between offered capital supply and demand capital, "regardless of the nature of goods, money, etc., used to transfer the lended value."

51. On this Saint-Simonian expansionist views of credit, see critical views from Walras presented in Kindleberger (1980).

52. According to Bentham, Thornton approved the Defence: "Thornton was there, and did homage to Def. Of Usury" (Milne, 1981, Letter 1188, 280).

53. Saint-Simon wrote no theory of money and credit, only an approach on bank organisation in industry.
} 
communications and exchanges easier, closing the accounts of achieved projects, and anticipating the opening of new accounts for new projects. Quoting Saint-Simon, their role was to be "general agents of the industry" were agents of credit, i.e. confidence, related not only to interest but also to sentiments. ${ }^{55}$ The Saint-Simonians considered money and confidence as equivalent, which was crucial, as credit was a peaceful way of insuring the progressive transfer of property to producers (without questioning the right to property). If non-producers (or producers who stopped their activity) trusted producers,${ }^{56}$ they would accept the transfer through a banking system as a principle of social order replacing the former guilds, just like the Physiocrats' laissez-faire. The banking system and credit were the "defensive weapon of workers" (Enfantin, 1826f, 83), the instruments to bring together, peacefully and progressively, property and workers. That approach of oriented transfer (not only intermediary) ${ }^{57}$ was predominant in the SaintSimonian conception of banking.

Second, they had to be organised as a hierarchical bank system ${ }^{58}$, contrary to what Smith and Say defended. That idea was already present in Saint-Simon's works and complied with the physiology of organisation in an economic and social system facing hierarchical flows. Banks are on the top of industrial hierarchy, put on top of each specific branch of industry (Rodriguez, 1825a, 164). Inside the banking system, the Saint-Simonians defended a dyad between centralisation (a central bank) and competition between other banks (later named "second order banks" in Doctrine, seventh lesson, 1830). This couple would become "national bank" and "free banks" in Decourtemanche (1832, dated June $7^{\text {th }} 1831$ in Le Globe). The Banque de France monopoly debate, which became central in France in relation to the issue of the Banque de Savoie in 1860-75, was not very present at the time apart from Fazy's opuscules $(1818,1826)$. The Saint-Simonians did criticise the Banque de France ${ }^{59}$ but not its monopolistic aspect. They attacked the insufficient exploitation of its privilege for the development of credit from the perspective of a bank that was necessarily central, but not public $^{60}$. The criticism of the current banking system regarding discount was also based on a hierarchical principle: the establishment of a loan and borrowing institution in order to base credit on the richest and most reliable borrowers. Their position was therefore very different from Say's - today they could be called "free banking" -, even though they did not include a modern thesis on lenders of last resort.

\footnotetext{
${ }^{54}$. Flows in the physiological metaphor of organisation were important in the Saint Simonian thought: banks were the major organisers of flows, i.e. the irrigation of the social workshop in all its parts, within the hierarchy of this workshop. On the transition from an old tradition of physiology of sensation to a new physiology of organisation, typical of early nineteenth century Saint Simonians.

55 . For example, see Enfantin's propositions of couples (1826m, 97), associating competition with violence and credit with faith.

${ }^{56}$. It should be noted that the Saint-Simonians considered that confidence had to be a one-way process: trust was not advised from producers to non producers, or the society would favour the idle (Enfantin 1826a: 19). Besides, the creation of confidence and promises did not use the inter-individual and specular process that could be found in the Scottish theory, in particular Hume: it was a convention involving the "relationship between the masses" (Enfantin 1826a: 20-21), with a hierarchy (the leaders of both classes, namely the richest idle and the most industrious workers, were the negotiators of the convention).

57 . Enfantin didn't really develop a problematic of savings: the funds were productive capital funds as production and land instruments. Capital holders and land owners destroyed their fund in consumed products if the transfer was not operated. The essential question was, again, that of the transfer of funds to their productive use (for product funds).

58 . That vision was absent from Say's writings.

59. For example in Enfantin (1826i, 66-67), or the diversion of the criticisms of Fazy (in Enfantin, 1826e, 47173).

${ }^{60}$. For example in 1826i, 96-97: "there is nothing to do as long as we have to fight against a privileged competitor. But it is not about struggling; it is about showing that the Bank does not use its privilege in the most useful way for its own interest."
} 
Third, banks were mixed or universal, i.e. 'industrial'. As Sraffa perceived it (1929), the Saint-Simonian banking system allowed an anticipation of the model of mixed bank or universal bank. According to Sraffa, two systems had to be distinguished. First, a system of specialised banks, as in England, focused on creating means of payment. Second, a system of mixed banks, as in Germany, focused on providing loans to firms and actually a partner of firms, far beyond credits. Mixed banks are said to have been originated by Pereire's attempts. Regardless of the meaning and context of Sraffa's analysis, ${ }^{61}$ the banking system did appear to be the organiser of industry in the Saint-Simonian perspective, with a system allowing a reduction of interest rate and a reduction of the risk premium component to the benefit of industrial organisation. Incidentally, in the Saint-Simonian thought, the question of hierarchy and network did not include the question of the State: private credit in a developed industrial society had to be very widespread and public credit very seldom used.

This whole analytical framework on interest and banking is critical to the understanding of the Saint-Simonians' views on the laws on usury and state-imposed interest rate. How the Saint-Simonians regarded state intervention in general is also important to precise their position further. The interpretations of the Saint-Simonian doctrine on the subject are quite different: some defend the criticism of 'liberal' state intervention (i.e. competitive bidding, the reference to a government that doesn't cost much and has few members, as in Say and Saint-Simon), and some others highlight the implementation by the Saint-Simonians of a true state technocracy. These apparent contradictions can be explained by the Saint-Simonian distinction between 'governing' and 'administrating', distinction made after Saint-Simon himself. The 'governing' State is the State of the feudal and aristocratic period, still present in the critical period that followed, with monopolistic interventions and a violent spirit. This is precisely the kind of State needed to be reduced, based on competition. But in the new historical step (the industrial organic period), the 'administrating' State is in place ${ }^{62}$ : in a physiologic perspective, the 'administrating' State is an organ totally integrated into the industrial and hierachical body. This is this body, with bank system on the top, which organizes the flows and replaces violence with conviction. The 'liberal' inclinations of the Saint-Simonians only happened in that context, i.e. the context in which Enfantin called for "free competition" between discount banks, at least as long as a general direction was not in place, with a substitution of tax credit as a softer transfer of resources to workers. ${ }^{63}$ It is in the context of the administrating State that Enfantin criticized the laws on usury, and was apparently close to Bentham or Say without ever mentioning them. ${ }^{64}$ As soon as he published his second article on discount banks (1826b), Enfantin was opposed to a fixed discount rate for banks. The richest bankers had to find an advantage in discounting the credit paper they deserved. Therefore, that rate had to vary according to the context, and the changing relationship between borrowers and lenders. Persuasion and confidence, based on the pilot role of some sub-assemblies of the socio-economic structure composed of the most important bankers and industrialists, played an important role in the industrial period. The defence of

\footnotetext{
${ }^{61}$. On that subject, see Panico (2001) and De Cecco (2005). Sraffa seemed to underestimate the fact that the Saint-Simonian bank system strictly aimed at specialising the establishments by industrial business segments ("one crediting centre to each industrial class" (1826h, 397), which probably created further compartmentalization.

62. The legislating State (Bentham's "Legislator of the World") complied the pre-industrial critical period and its transition to the next period (with the role of 'jurists'). We think that the different conceptions were only the consequence of the subtle transition, at the turn of the nineteenth century, from theories of sensation and transformed sensation to a theory of organisation with various physiological references in all three cases.

63 . For example, $1826 \mathrm{~g}, 225$ and next.

${ }^{64}$. Just like Bentham, Say criticised Smith: "I cannot understand why Smith approves fixed interest rates in England" (1803, t. 1, 770).
} 
"free rate" (discount and interest) was permanent in the Saint Simonian writings at this time. The argument in support of "free rate" was threefold. First, it was based on the defence of "cosmopolitan bankers" against criticisms for usury loans (1826b) and against the laws on usury, grounded on the fact that the industrial government should not be based on laws but on means of association. Second, it opposes the supposed efficiency of the repressive laws on usury. Quite on the contrary, these laws resulted in "more expensive advances from lenders" whereas "what needed to be fought was dissipation rather than usury" (1826f, 81). Third, it insisted on the defense of preventive means rather than repressive means ("Credit, the defensive weapon of workers", 1826f, 83). ${ }^{65}$

The Saint-Simonian writings and consequent debate within the Saint-Simonian School all derived from Bazard's work, still in progress in 1828: for instance, state regulation of usury will never be advocated.

\section{Bazard's analysis of Bentham's Defence and the significance of its references to Utilitarianism}

In the annotated translation of Bentham's Defence ${ }^{66}$ and in the preliminary dissertation (1828), Bazard took up important elements of the position elaborated by his fellow thinkers in 1825-26 and previously introduced. Most significantly, he made a very original contribution by integrating Bentham's ideas directly in his thought: the Saint-Simonian disciples had never quoted the Defence (1787) before. Even though Enfantin's arguments opposing the laws on usury were particularly close to Bentham's (about their ineffectiveness, for example $)^{67}$, Bazard was really the only Saint-Simonian who quoted Bentham in that debate. ${ }^{68}$ Bazard's personal background, his particular interest in the Utilitarian author, and his special relationship with Dumont all were important factors, of course. The dissertation raises the following questions: what specific arguments did Bazard find in Bentham's thought on interest rate and usury? More generally, what is the surprising 'common ground' between Saint-Simonism and Utilitarianism?

Bazard immediately insisted on the need to get rid of legally fixed interest rates and showed that in terms of legislation, France was late: "Even France did not clear its codes from those measures. The defects of that part of legislation have long been felt and reported." (ibid, 3) With the development of political economy, France was however about to overcome these preconceptions, particularly thanks to Bentham's integration. Bazard notably insisted on the fact that both Bentham and himself considered individual freedom as a minor argument for their protest. ${ }^{69}$ What was essential to Bazard was to show that the law had no effect anyway. Bazard thus insisted very precisely on the Benthamite use of the principle of utility and its consequentialist assumption to protest against the effects of laws on usury. ${ }^{70}$ Bazard validated

\footnotetext{
${ }^{65}$. Necker's opinions (1775) were evoked, and even Sully's (in his Mémoire in 1630), about the skilful way of changing the proportions in the classes of the nation living from their work, compared to the other classes.

${ }^{66}$. Bazard translated the fourth English edition, published in 1818, more accurate than Delessert's translation (1790) of the first edition.

${ }^{67}$. Bentham (1787), Letter 6.

68. Enfantin mentioned Bentham positively six times in four articles he wrote in Le Producteur (including two articles on the subject of interest: 1826j, 145 and 1826c, second letter, 224), but never about the Defence.

69. See 1828,4 and 5 on that crucial subject.

70 . This is to be found in Bazard's introduction, where he evoked other works written by Bentham on the principle of utility, but also in the first translator's note of Letter III: Bentham indicated that, generally speaking, the legislator's intervention could be justified, and evoked the comparative calculation of penalties which was
} 
Bentham's demonstration, insisting on his Utilitarian background, and agreed with his conclusion: the laws on usury had to be withdrawn.

This paradox relied on the fact that Bazard acknowledged Bentham's thought while putting himself in a different intellectual context. Indeed, Bazard also writes that he disagrees with Bentham on the theory of interest. Three elements explain this apparently contradictory position.

First, concerning the origin of interest. For Bentham, interest is a return on capital earned for abstinence, risk, and for managerial efforts from investors (or "projectors"). For Bazard however, only labour creates value and products: money interest, or interest as price for a capital service is a fake, as interest is but the payment of a rent for physical goods, namely capital (i.e. work instruments), just like rent is used for land loan. This is of course the SaintSimonian view presented in the previous section.

Second, concerning individual utility. The point is to withdraw the laws, not in the name of individual freedom but under a totally different argument: a general law of evolution, which has nothing to do with a possible individual calculation of utility. The preconception against usury was rooted originally on the poor protesting against the rich; a protest that revealed a trend in the progress of societies:

The issue of interest is actually a political issue. The rent of work instruments is the expression of the social combination apprehended in its most general aspect, combining up to now workers and non workers; the decrease observed in the rate of this rent is mostly due to the decrease of the principle of this social combination, i.e. the appreciation of values in the hands of workers $(1828,21-22)$.

Therefore, the paradox of a Saint-Simonian advocating economic liberalism finds a first and immediate answer: Bazard's support of economic liberalism was not based on a criticism of State intervention in the laws on usury, contrary to the usual - though extremely simplistic interpretation of Bentham's thought in the nineteenth century. Bazard's translation and interpretation are a pretext to a globalist and evolutionary interpretation of the Saint-Simonian thought. The reference to "the march of the world", a general law or trend of a credit function within the industrial organisation is highlighted, regardless of the different individual levels of pleasure and pain.

Third, when it comes to risk, especially in the famous Defence's XIIIth letter, Bentham advocates a floating interest rate under the name of a limited number of innovators willing to bear important risk (the "innovative spirit") and as a criticism against the complete ignorance of the legislators towards these questions. For Bentham, innovation automatically means higher risk and should not be artificially distorted. ${ }^{71}$ Quite on the contrary, Bazard never evokes individual risk and the lottery of innovation in his dissertation. The risk premium is an integral part of the interest rate that should be internalized through risk sharing thanks to a new organization of credit and universal association. The historical and economic forces defined by Saint-Simonians should therefore provoke its "natural" decrease. Besides, industrial risk for the Saint-Simonians was fundamentally opposed to game risk, regarded as speculative and proper to critical periods: players are opposed to workers; "game-speculationgambling and industry are false friends"; "working spirit is killing game spirit" (Enfantin, Rodrigues 1825, or Enfantin, 1826k on futures contracts). Moreover, in 1787 Bentham did not

then necessary for the spendthrift; Bazard felt he had to remind that the whole reasoning was based on that principle, mentioning the Traités de Législation (edited by Dumont, 1802).

71. Also in Chapter 14 of the manuscript Manual of Political Economy (1795), in Dumont's version in 1811 (which Enfantin and Bazard read): to Bentham, the spirit of game was useful for the development of trade and arts, and a fixed interest rate on money was an obstacle to that development. 
mention the use of credit to finance projectors. He probably favored savings over credit (Sigot 1998) as his study of monetary creation as a financing tool (1801) led him to believe that inflationary risks were non negligible. Monetary creation should only be used to finance lowrisk and short-term investments.

With all theses differences, it would be tempting to conclude that the reference to Bentham by Bazard is nothing more than a trick or a pretext. This is not what we think, as explained in the last section.

\section{On the significance and relativity of the Saint-Simonism / Benthamite Utilitarianism relationship}

We believe that an interpretation simply based on a "Bentham as a pretext" kind of argument would seriously underestimate the role of the Utilitarian references in Bazard's work, as well as in many other Saint-Simonian authors (Bellet 2011b). Bentham's Defence of Usury (1787) was often wrongly interpreted as the symbol of absolute economic Liberalism rejecting State intervention, regardless of the patent contradiction with the claimed role of the Legislator. Bentham's thought cannot be understood without introducing the relationship with the general theory of utility (or happiness). Bentham considered political economy as a branch separated from legislation, aiming at the greatest happiness to benefit the most people, but with a specific intermediary objective: abundance and subsistence. Contrary to the objective of safety and equality, the objective of abundance did not require State intervention because the action of individuals was enough. By intervening, the State would have created additional pain and not additional pleasure. The laws on usury were thus related to non-intervention understood as 'non agenda'. Bentham protested against the laws limiting interest rate in that specific context. But one should not conclude that Bentham rejected State intervention in every possible context (his famous "Be quiet" dictum). The interference between the intermediary objectives of legislation and political economy made his analysis much more complex, as shown by the areas of 'agenda' and 'sponte acta' (Guidi, 1990).

Still, at the time of Saint-Simon and Saint-Simonians, that position had not been acknowledged in detail. What was understood of Bentham's pamphlet was mostly a principle of 'liberty', meaning that no one should be restricted by the laws against usury or accept a higher usury rate than the market one. But we have seen that this wasn't Bazard's analysis. Therefore, Bazard's had certainly noticed something more in Bentham's thought for him to prove such a strong interest in his work. There had to be some common grounds between the Saint-Simonian approach and the Benthamite approach. The major common ground was common or general utility, i.e. what Mongin (1995) called the collective component of the principle of utility, cut off from its individual utility basis in all Saint-Simonian references. According to the Saint-Simonians, the principle of (general) utility corresponded to the industrial principle, giving utility a true content. Bentham's 'felicific calculus' related to the principle of utility was replaced by a methodology associating the industrial principle with history: the creation of historical laws allowing for a social accounting between the periods of social life. The Benthamite "greatest happiness of the greatest number" corresponds to "the improvement of the moral and physical existence of the most numerous and poorest class" 72 . It is because of this "common ground" that Bazard rejects the usual analogy between Bentham and the enlightened self-interest philosophy inherited from Helvetius and

\footnotetext{
72. This formula synthesizes the Saint-Simonian vision of welfare (see the epigraph consistently mentioned in $L e$ Globe from January 1831 to April 1832).
} 
d'Holbach, but also from Say. This critical point is also revealed in l'Exposition de la Doctrine through the difference between the $8^{\text {th }}$ and the $9^{\text {th }}$ session, i.e. between a respectful critique of Bentham regarding private ownership ${ }^{73}$ and a sharp criticism of the "enlightened self-interest" morality, which is not targeting Bentham ${ }^{74}$. This morality is limited to the following principle: "Understand your interest well, and all will be for the best" ([1830] 1972, 145). On the contrary, Bazard argues Bentham's philosophy contains a social morality. This morality do not result from the natural harmonization of interests. It also asks for the Legislator's intervention so as to reach an artificial harmonization of these very same interests (Baujard 2010). Therefore, the Benthamite Legislator corresponds to the Saint-Simonian Organizer. The criticism of the role of the State in terms of legislation against usury corresponds to the criticism of the role of the governing State (feudal period), whereas the administrating State (industrial period) is based on trust or credibility and the dynamics of historic laws (the decrease of interest rate, for example). The Saint-Simonians do not advocate a statist view of social organization but a hierarchical view in which government functions are embodied within industry, and more precisely within banking (which is not public, as we seen before). Bazard and his school do not have a Statist economy in mind but an industrial, scientific and religious expertise orienting a mass of society members ("sociétaires") organized in corps. In the industrial stage of this economy, the diverse functional components are linked towards one another through a trust-credibility feeling. This feeling is nothing but one of the shapes taken by the Benthamite concept of sympathy once the "positive religion" manifests itself.

This convergence is not so surprising as it had already been pointed out by Bazard as soon as 1825 in a text entirely devoted to a comparative summary between Saint-Simon and Bentham. In this text, the Saint-Simonian School introduced Saint-Simon as Bentham's successor $^{75}$. At least three points of convergence can be mentioned. First, according to the disciples, both Utilitarianism and Saint-Simonism present a positive system (as opposed to a metaphysical system): the Saint-Simonians adhere to both Bentham's and Saint-Simon's rejection of the Original Contract. Legislation based upon natural rights (Hobbes, Rousseau,...) does not have any clear foundation due to the differing definitions of Human Nature, Reason, Conscience, etc. For Duvergier $(1825,200)$, "it is to Bentham's credit that he abandoned a false path and showed the right path": ${ }^{76}$ by "demonstrating the purpose of legislation by saying that its aim was for General Utility", Bentham defended a positive system. "The most desirable conventions are, according to Bentham, those whose results are of the greatest use ${ }^{77}$." The second convergence point highlights the fact that there is a single or common principle and a unified science, both related to Utility and Happiness. For Bentham everything derives from the Principle of Utility and the accounting of pains and pleasures; for the Saint-Simonians everything derives from the organizational principle ${ }^{78}$,

\footnotetext{
73. It contains an extremely respectful critique of "the work of the great legist who attempted to bring all laws under the head of one principle" ([1830] 1972, 132). This critique deals with the question of inheritance, aiming at a better understanding of the theory of (general) utility. Indeed, favoring capacity-based transmission over inheritance, as proposed by Saint-Simonians, aligns with the historical tendency of increasing global utility.

74 . That session was written by Bazard in 1829 .

75 . In Duvergier (1825). The jurist Jean-Baptiste Duvergier (1792-1877) was among the first of Saint-Simon's disciples, with Rodrigues and Enfantin.

${ }^{76}$ See also Enfantin (1826a, 224-5) who argues against Constant, « Bentham demonstrated the futility of the Theory of Human Rights... Instead of evaluating the rules by comparing them with the principles of Natural Law, Bentham believed that they should be judged according to their results », which is « remarkable progress ». 77 . In 1826b, 144-145, concerning the Encyclopédie Progressive and an article by Say.

78 . The Saint-Simonian "social accounting", based on evolutionary laws, does not explicitly refer to Bentham's principles of addition and maximization. The computation relies on a (more or less significant) discrepancy between the present social organization and what the "general march of humanity" would require.
} 
linked to production and industry with its three orders: moral, scientific and industrial. Finally, the third convergence point bears upon the possibility of linking individual interests and the general good, within the framework of institutional reforms. Social Utility (or "Collective Utility», or "General Utility » according to Duvergier) in relation to the usefulness of each member of society may be defined by an institutional mechanism. ${ }^{79}$ And although the mechanism of aggregation and the convergence of individual interests are different for the two Schools, it is through the institution that the degree of Social Utility is expressed. The positive nature of Utilitarianism and its derived Consequentialism, the presence of a general utility principle can all be identified as common traits between Utilitarianism and Saint-Simonism. Bazard's interpretation of the Defence three years later is thus nothing but the economic peak of this convergence.

We showed that the Benthamian filiation of Saint-Simonism was not artificial, even though it included some ambiguities, incidentally revealed when the Saint-Simonians changed their attitude in the last stage of their work, starting from 1831. Then, they started analyzing Bentham's work strictly through its individual utility aspect, and almost systematically associated him to the supporters of interest and enlightened interest. Bentham was now considered as a doctrinarian of the "upsetting theories of selfishness". The Saint-Simonians made more and more critical allusions on the Benthamites or Bentham's disciples. For example, Laurent ${ }^{80}$ (1831) criticised the Benthamites who presented poverty as permanent, with the "cold reason of economists" 81 and remained "indifferent to the people's sufferings". Some writings then refused to come out in favour of the theorists of natural law or the Benthamites. Bentham (and especially his so-called "disciples") was then considered as a supporter of the theory of selfishness. For example Transon ${ }^{82}$ (1831) was very clear on that point: to the "supporters of utility and of enlightened self-interest" (for the first time both discredited in a same expression),

We show that man is not only a calculating being, but mostly a feeling being; utility, as well as truth and beauty, is relative to the development of civilization; incidentally, the principle of utility cannot just be proclaimed; but to be able to agree on enlightened interest, everyone should be able to obey men who desire their progress and are in a position to have them like their true interest; now, men can only be willing to obey in a religious society $(1831,421)$.

For the first time, the Saint-Simonians approved an analysis of Bentham's work that existed in the enemies of Utilitarianism, and later became the dominant analysis, contrary to their first opinion. The interpretation in terms of social utility, which led to a basically favorable opinion on the jurist reformer, was abandoned. Bentham was ranked as a theorist of individual utility, typical of critical periods. Changing their mind, the Saint-Simonians joined the early enemies of Benthamite Utilitarianism (and sometimes the 'liberal' enemies of SaintSimonism such as B. Constant or Mme de Staël).

\footnotetext{
79. « We admire Bentham too much to leave his work unmentioned. He has seen that it is by their usefulness that institutions could be legitimised... » (Enfantin et alii, 1830, $8^{\text {th }}$ session, 163).

80. Paul-Mathieu Laurent (1793-1877) is a jurist and a publicist, founder of the saint-simonian journal L'organisateur (1829-1830), then editor for the journal Globe, which became a Saint-Simonian journal between 1830 and 1832 . He only had weak exposure to the work of Bentham.

'. It wasn't the case in 1826, when Bazard wrote a positive review of Bentham's Pauper Management (1797).

${ }^{82}$. Abel Transon (1805-1876) a polytechnician, a mathematician and a publicist, editor for the journal Le globe and author of several Prédications. He broke with the Saint-Simonian Family in the same time that Bazar and Enfantin's dispute. (December 1831-January 1832).
} 
We can think of three main reasons for this turnaround. First, the revolutionary days of July 1830 marked a change in historical context: the Restauration is over. The fall of Charles $\mathrm{X}$ and the institution of the "July monarchy" with Louis Philippe is the result of a popular revolution. The republicans received the support of the Parisian people: workers, craftsmen, shopkeepers, but also students and the national guards. Of course, this "People" lost on the $30^{\text {th }}$ of July with the rise of Louis-Philippe and his partisans, but this popular insurrection surprised the Saint-Simonians. The republican riots, the rise of the "proletariat", the reference to the "right to work" (see the Luddite movement during 1830-1832, and the first Canuts riots in Lyon in November-December 1831) gave rise to a tension within the theory itself: the definition of "workers" by Saint-Simonians appeared too holistic. The Benthamite philosophy became mostly associated with the economic "laisser-faire", especially in France, and even worse, with the social "laisser-faire", at a time where the social question was of major importance.

Second, the intellectual context also played an important role. The religious dimension largely developed itself within the Saint-Simonian School (Steiner 2008). Even though they advocated a positive religion (meaning an "industrial" religion), they also felt a growing desire not to be compared to sensualist materialism (under its strict or modified version), or to atheism. However, an overly simplistic but dominant interpretation associated Bentham with a sensualist and atheist tradition. From this original mistake, it was an easy step to rank Bentham among authors such as Helvétius, d'Holbach, Cabanis, or Volney. The distinction between "supporters of utility" and "supporters of enlightened self-interest" (as in the Exposé de la Doctrine, 1830) therefore became inappropriate.

Finally, this new interpretation of Bentham was amplified after Bazard broke-up with the Saint-Simonian School at the end of 1831. Bazard was the best specialist of Bentham's thought and with his departure, it became much harder for him to oppose the simplistic analogy between Bentham and the support of "laisser faire". He also proved more difficulties to define rigorously the identity of the "Bentham disciples" in France. Economic liberalism and Benthamism became twin concepts, confirming the ambiguity behind the notion of "varieties of liberalism" in France (Staum, 1998).

The Saint-Simonian turnaround surely played a crucial role in the absence of filiations between Utilitarianism and socialist movements in continental Europe (as opposed to the Anglo-Saxon society). However, despite this drastic change in the interpretation of Utilitarianism, Bentham's conclusion regarding legal caps on interest rates will never be opposed in future Saint-Simonian economic texts.

\section{Summary and Conclusion}

Bazard's translation of the Defence and his dissertation are the most symptomatic economic illustrations of the relationship between Saint-Simonism and Benthamite Utilitarianism. We believe that this relationship was not only a pretext as it was based, particularly for Bazard, on a long and patient reading experience and on a friendship with Dumont hitherto unrevealed. That filiation resulted from a very selective interpretation of Benthamite Utilitarianism, based solely on the aspect of social or general utility, as opposed to the theories of individual interest. We showed how Bazard refered to the Saint-Simonian views on money and banking to justify a convergence between Bentham's conclusions on usury laws and the SaintSimonian historical tendency of the rate of interest to fall. However, this very peculiar convergence did not last for long: as soon as 1831, Saint-Simonism rallied the dominant 
interpretation according to which Utilitarianism was synonymous with "laisser faire" and selfishness. Therefore, Bazard's attempt did not manage to prevent the unilateral assimilation between Utilitarianism and economic Liberalism in continental Europe, which became a point of no return from the $19^{\text {th }}$ century onwards.

\section{References}

Allier, Joseph. 1826. Crédit, discrédit, banquiers, industriels, producteurs. Le Producteur II.25:566-576.

Baujard, Antoinette. 2010. Collective interest vs. individual interest in Bentham's felicific calculus. Questioning welfarism and fairness. The European Journal of the History of Economic Thought. 17. 4:431-453.

Bazard, Saint-Amand. 1814. Lettre à Etienne Dumont, April 23. Unpublished letter. Département des Manuscrits, Fonds Dumont, MS 33.IV.f. 1-7. Bibliothèque Publique et Universitaire de Genève.Suisse.

-----. 1815. Lettre à Etienne Dumont, August 16. Unpublished letter. Département des Manuscrits, Fonds Dumont. MS 33.IV.f. 1-7. Bibliothèque Publique et Universitaire de Genève.Suisse.

-----.1816. Lettre à Etienne Dumont, August 10. Unpublished letter. Département des Manuscrits, Fonds Dumont. MS 33. IV.f. 1-7. Bibliothèque Publique et Universitaire de Genève. Suisse.

-----1818. Lettre (destinataire perdu), May 30, unpublished letter, Département des Manuscrits D.O. 1932/567, 1f. Bibliothèque Publique et Universitaire de Genève, Suisse.

----.1820. L'Aristarque français, articles Feb. 14, 17, 23 and 27 ; March 4 , 7, 9 , 14, 16, 22 and 23 (signed by St. A.B. ou St-A B...d), documents Bibliothèque Nationale de France FOL-LC2-1016 et MICR D-1702

-----.1824. Lettre à Etienne Dumont, July 23, unpublished letter, Département des Manuscrits, Fonds Dumont, MS 77, f. 1-2, Bibliothèque Publique et Universitaire de Genève, Suisse.

-----. 1825. Des partisans du passé et de ceux de la liberté de conscience. Le Producteur. I. 9:399-412.

----- 1826a. Notice sur les ouvrages de Bentham. Revue encyclopédique XXXI.92:298-307 (article signed by « Saint-Amand »).

-----. 1826b. Papers relative to codification and public instruction, including correspondence with the Russian Emperor, and divers constituted authorities in the American United States;published by Jeremy Bentham. Pièces relatives à la codification et à l'instruction publique... ». Revue encyclopédique XXXI.93:626-41 (article signed « Saint-Amand »).

-----. 1828. Introduction contenant une dissertation sur le prêt à intérêt. In Défense de l'usure, ou Lettres sur les inconvénients des lois, qui fixent le taux de l'intérêt de l'argent, par Jérémy Bentham, traduit de l'anglais sur la 4 è edition, suivi d'un mémoire sur les prêt d'argent, par Turgot. Paris: Malher et Compagnie.

-----. [1832] 1963. Lettre à Rességuier. Reprint in Oeuvres de Saint-Simon \& d'Enfantin. Notices Historiques II 1865-78. Reprint Vol.VII:41-62 in Aalen: Otto Zeller.

Bellet M. 2009. On the Utilitarian Roots of Saint-Simonism:From Bentham to Saint-Simon. In The political economy of the Saint-Simonians, edited by A. Zouache. History of Economic Ideas, special issue, $\mathrm{XVII}(2): 41-63$.

-----. 2011a. Five unpublished letters from Bazard to Dumont. Presentation in Lettre des Etudes SaintSimoniennes 24, February.

-----. 2011b. Utilitarianism and Saint-Simonism:Saint-Simon's Disciples and Benthamian Utilitarianism. Working Paper. GATE Lyon-Saint-Etienne. CNRS.

Bentham, Jeremy. 1787. Defence of Usury; Shewing the Impolicy of the Present Legal Restraints on the terms of Pecuniary Bargains in a series of letters to a friend to which is added a letter to Adam Smith, Esq; LL.D. On the Discouragements opposed by the above Restraints to the Progress of Inventive Industry.

-----. [1787] 1790. Apologie de l'usure, rédigée en Forme de Lettres, adressées à un Ami... traduit de l'Anglois de Jérémie Bentham. Paris: Lejay fils.

-----. [1787] 1790. Lettres sur la Liberté du Taux de l'Intérêt de l'Argent par Jérémie Bentham, translated by par E. Delessert. Paris: Grégoire. VII.

-----. [1787] 1817. Defence of Usury. Défense de l'usure : exposé des inconvénients résultant des lois qui limitent le taux d'intérêt dans les conventions pécuniaires. Par M. Jérémie Bentham. $3^{\text {rd }}$ édit. Londres 1816 (Extrait communiqué par Mr. Dumont). Bibliothèque universelle des sciences, belles-lettres et arts. Genève $\mathrm{V}: 3-11$.

-----. [1787] 1828. Défense de l'usure ou lettres sur les inconvénients des lois, qui fixent le taux de l'intérêt de l'argent, par Jérémie Bentham, traduit de l'anglais sur la $4^{\text {ème }}$ édition; suivi d'un mémoire sur les prêts d'argent, par Turgot, et précédé d'une introduction contenant une dissertation sur le taux d'intérêt. Paris: Malher et Compagnie.

-----. [1787] 1830 Défense de l'usure in Euvres de J. Bentham, jurisconsulte anglais vol.II. Bruxelles: Louis Hauman et compagnie. 
-----.[1787] 1952. Defence of Usury, in Jeremy Bentham's Economic Writings, by W. Stark, London and New York: Routledge 1:121-207.

-----. [1796] 1981, Letter to Samuel Bentham, 7 October 1796, in The Correspondence of Jeremy Bentham, Vol. 5. January 1794 to December 1797. Ed. A.T. Milne. London: The Athlone Press.

-----. 1802, Traités de législation civile et pénale, 3 vol., Textes traduits et traités par Dumont E., Paris: Boussange, Masson et Besson.

----. 1811. Traité des peines et des récompenses, 2 vol., Textes traduits et traités par Dumont E., London, B. Dulau.

----- 1816. Tactique des assemblées législatives, suivi d'un traité des sophismes politiques, 2 vol., translated and organized by Dumont E., Genève et Paris : J.J. Paschoud.

----- 1817. Plan Of Parliamentary Reform, in the form of a Catechism, with Reasons for each article, with an introduction shewing the Necessity of Radical, and the Inadequacy of Moderate Reform. London: printed for R. Hunter, successor to Mr. Johnson.Comte, Auguste.

----. 1801. Sur les prix. Manuscript in French trans. by E. Dumont: Matériaux d'un traité sur la hausse des prix et les effets du papier-monnaie. Département des Manuscrits, Bibliothèque Publique et Universitaire de Genève. Suisse.

Béranger, Charles. 1832. Les prêteurs à la petite semaine. Les banquiers. Les banques saint-simoniennes, Feuilles populaires. Paris: Everat.

Blamires, Cyprian. 2008. The French Revolution and the Creation of Benthamism. New York: Palgrave Macmillan.

Cardoso José Luis de, de Vasconcelos Nogueiria, Antonio. 2005. Isaac de Pinto (1717-1787) : An Enlightened Economist and Financier. HOPE 37(2):263-292.

Carlisle, Robert B. 1988. The Proffered Crown: Saint-Simonians and the Doctrine of Hope. Baltimore: Johns Hopkins University Press.

Charléty, Sébastien. 1931[1965]. Histoire du saint-simonisme (1825-1864). Paris: Gonthier.

Coco, Giuseppe, De Meza, David. 2009. In Defense of Usury Laws. Journal of Money, Credit and Banking 41.8:1691-1703.

Conway, Stephen (ed). 1988, 1989, 1994. The Correspondence of Jeremy Bentham.Vol. 8 (January 1809 to December 1816), Vol. 9 (January 1817 to June 1820), Vol.10 (July 1820 to December 1821). The Collected Works of Jeremy Bentham (ed. F. Rosen), Oxford: Oxford University Press

Crimmins, James. 1998. Political Economy and Projectors: Bentham's Defence of Usury. Conference paper. St. Petersburg Center for the History of Ideas, 58-72.

De Cecco, Marcello. Sraffa's Lectures on Continental Banking: A Preliminary Appraisal. Review of Political Economy 17(3):349-358.

Decourdemanche, Alphonse. [1831] 1832. Sur la législation dans ses rapports avec la propriété. Paris: Bureau du Globe. $4^{\text {th }}$ letter (De la création de nouvelles banques), $10^{\text {th }}$ Letter (Influence de la mobilisation du sol et de la création de banques libres sur la destinée sociale) and $12^{\text {th }}$ Letter (Considérations générales sur les finances), from Le Globe, Dec. 22, 1830, June 7, 1831, August 1, 1831). The two first Letters are translated in English in Jacoud (2010), chap. 5 and 15.

Dubochet, François. 1826. De la spéculation. Le Producteur IV.2:30-42.

Dumont, Etienne. 1832. Souvenirs sur Mirabeau et les deux premières assemblées législatives. Ouvrage posthume publié par M.J.L. Duval. Paris: Charles Josselin.

Duvergier, Jean-Baptiste. 1825. De la législation. In Opinions littéraires, philosophiques et industrielles [Bailly Dr, Duvergier J.-B., Halévy L., Rodrigues O. and Saint-Simon H.]. p.199-225. Paris: Bossange Père.

1834. Collection complète des lois, décrets, ordonnances. I:343. Paris: Guyot et Scribe.

Enfantin, Prosper 1822. Lettre à Etienne Dumont. $1^{\text {er }}$ septembre. De St-Pétersbourg. Unpublished letter, Département des Manuscrits, Fonds Dumont, MS 75. Bibliothèque Publique et Universitaire de Genève, Suisse.

-----. 1825. Considérations sur la baisse progressive du loyer des objets mobiliers et immobiliers. Le Producteur I.6:241-254 and 12:555-567.

----. 1826a. Des banques d'escompte. Le Producteur II.14:18-33 and 16:109-125. Translated in English in Jacoud (2010), chap.2.

-----. 1826b. Des banquiers cosmopolites. Le Producteur II.17:205-211.

----. 1826c. Conversion morale d'un rentier. $1^{\text {ere }}$ lettre, $2^{\text {ème }}$ lettre et Poscriptum, $3^{\text {ème }}$ lettre. Le Producteur II.2:401-411. IV.2:212-243 and 366-371 and 434-453.

-----. 1826d. Réflexions sur quelques questions de douanes et de finances, discutées actuellement en France et en Angleterre. Le Producteur II.22:420-427.

-----. 1826e. Opuscules financiers. [sur l'ouvrage de Fazy J.-J.]. Le Producteur II.23:470-480.

-----. 1826f. Considérations sur l'organisation féodale et l'organisation industrielle. Le Producteur III:66-85.

-----. 1826g. Du système d'emprunts comparé à celui des impôts. Le Producteur III.2:215-252. 
------. 1826h. De la concurrence dans les entreprises industrielles. Le Producteur III3:385-409.

----- 1826i. De la circulation. Echange, vente, promesse, produits, monnaie, papier. Le Producteur. IV.1:37-67.

----. 1826j. Economie politique, par J.-B. Say. In Mélanges. Le Producteur. IV.1:138-146.

-----. 1826k. Mémoires sur les engagemens de Bourse, dits marchés à terme. In Mélanges. Le Producteur IV.1: $146-153$

-----. 18261. Considérations sur les progrès de l'économie politique, dans ses rapports avec l'organisation sociale. Deuxième article. Quesnay, Turgot. Le Producteur.V:17-47.

-----. 1826m. Nouveaux principes d'économie politique, de Sismondi, in Mélanges, Le Producteur V:94-98.

-----. [1827] 1963. Correspondance inédite, XXIVème lettre, à Résseguier, in 1868, Euvres d'Enfantin, Paris, Dantu éditeur reprint Euvres de Saint-Simon \& D’Enfantin. Aalen: Otto Zeller.

----. 1831. Economie politique et politique. Paris. Bureau du Globe.

Enfantin, Prosper, Rodrigues, Olinde 1825. De la crise des fonds publics, de la spéculation en général, et du jeu de la Bourse. Le Producteur I.7:330-336.

Enfantin, Prosper, Carnot, Hippolyte, Fournel, Henri, Duveyrier Charles. 1830, Doctrine de Saint-Simon. Première année. Exposition, 1829, Paris, au bureau de $1^{\prime}$ Organisateur $\left[7^{\text {th }}, 8^{\text {th }}\right.$ and $12^{\text {th }}$ sessions].

Faccarello, Gilbert, Steiner, Philippe. 2008. Religion and Political Economy in Early-Nineteenth-Century France. HOPE 40:26-61.

Fazy, Jean-Jacob (or James). 1818. Le privilège de la Banque de France considéré comme nuisible aux transactions commerciales. Paris.

-----. 1826. Opuscules financiers sur l'effet des privilèges, des emprunts publics et des conversions, sur le crédit de l'industrie en France. Paris/Genève: J.J. Naudin et Ponthieu/Barbezat et Delarue.

Forbonnais, François Véron de. 1758. Recherches et Considérations sur les finances de France, depuis 1595 jusqu'à 1721. Deux tomes, Basle: aux dépens des frères Cramer.

Fuller, Catherine. 2000. The Correspondence of Jeremy Bentham.Vol. 11 (January 1822 to June 1824). The Collected Works of Jeremy Bentham (ed. F. Rosen). Oxford: Oxford University Press

Guidi, Marco E. L.1990. 'Shall the blind lead those who can see?" Bentham's theory of political economy. In Perspectives on the History of Economic Thought (Vol. III) edited by Donald E. Moggridge. History of Economics Society. Brookfield: Edward Elgar.

Halévy, Elie. 1908. La doctrine économique des saint-simoniens. La Revue du Mois 31:39-75.

Hollander, Samuel. 1999. Jeremy Bentham and Adam Smith on the Usury Laws:A 'Smithian' Reply to Bentham and a New Problem. European Journal of History of Economic Thought 6.4:523-551.

Iggers, Georges G. (transl.) 1972. Introduction, in The doctrine of Saint-Simon: an exposition. First year, 18281829. Transl. with notes. 2sd ed. New York: Schocken Books. Studies in the libertarian and utopian tradition.

Jacoud, Gilles. 1998. A national bank or local banks? Debates on the issuing of paper money in France in the first half of the nineteenth century. In Bellet M. and L'Harmet C. (eds) Industry, Space and Competition. The Contribution of Economists of the Past. Cheltenham: Edward Elgar.

-----. (ed.) 2010. Political Economy and Industrialism. Banks in Saint-Simonian economic thought. Abingdon/New York: Routledge

Laffitte, Jacques. 1824. Réflexions sur la réduction de la rente et sur l'état du crédit. Paris: Bossange père.

Laurent, Paul-Mathieu. 1831, Prédication du 23 octobre, Le parti politique des travailleurs est désormais constitué, Le Globe, 24 octobre, reprint in 1832, Prédications, nIX. L'hérédité. Paris: Everat. 175-189.

Law, John 1705 [1720-1790]. Money and Trade Considered: With a Proposal for Supplying the Nation with Money. Edinburgh: Andrew Anderson, in The Avalon Project, by R. Hay. French translation in 1720, Considérations sur le commerce et sur l'argent, La Haye: J. Neaulme, and 1790, Euvres de J. Law, contrôleur des finances de la France sous le Régent : contenant les principes sur le numéraire, le commerce, le crédit et les banques : avec des notes, trad.. by Etienne de Sénovert. Paris: Buisson. Partial Reprint in 1843. Considérations sur le numéraire et le commerce, Mémoires et Lettres sur les Banques, Opuscules divers. In Economistes financiers du XVIIIème siècle. Paris: Guillaumin.

Le Moniteur. 1802. Révolution Française. Table alphabétique du Moniteur de 1787 à 1799. I. 235. Aix-Paris: Girardin.

Leloup, Sandrine. 2000. «Pour en finir avec l'usure : l'enjeu de la controverse entre Adam Smith et Jeremy Bentham. Revue économique 51.4:913-936.

Manuel, Frank Edward. 1962. The Prophets of Paris. Harvard: Harvard University Press.

Milne, Alexander (ed.). 1981. The Correspondence of Jeremy Bentham, Volume 5 (January 1794 to December 1797). London: The Athlone Press.

Mongin, Philippe. 1995. L'utilitarisme originel et le développement de la théorie économique, in La formation du radicalisme philosophique by Elie Halévy (1904). III, Postface. Paris: Presses Universitaires de France.

Marmont du Hautchamp, Bartelemy. 1739. Histoire du système des finances sous la minorité de Louis XV pendant les années 1719 \& 1720 précédée d'un abrégé de la vie du duc Régent, \& du Sr. Law. La Haye : Pierre de Hondt, 2 tomes. 
Molinari, Gustave de. 1848. Mélanges d'économie politique, $2^{\text {nd }}$ part. précédés de notices historiques, J. Bentham, Lettres sur la défense de l'usure, ou Lettres sur les inconvénients des lois qui fixent le taux d'intérêt de l'argent, précédés d'une introduction sur le prêt à intérêt, Collection des principaux économistes, tome 15. Paris: Guillaumin et Cie.

Murphy, Antoin E. 1997. John Law: Economic Theorist and Policy-Maker. Oxford: Clarendon Press.

Musso, Pierre (s.d.) 2004. L'actualité du saint-simonisme. Colloque de Cerisy. Paris: Presses Universitaires de France.

Necker, Jacques. 1784. De l'administration des finances de la France. 3 vol. Paris: Panckoucke.

Necker, Jacques. 1775. La législation et le commerce des grains. 2 vol. Paris: Pissot.

O'Sullivan, Luke and Fuller, Catherine (eds). 2006. The Correspondence of Jeremy Bentham.Vol. 12 (July 1824 to June 1828) in The Collected Works of Jeremy Bentham edited by Frederik Rosen. Oxford: Oxford University Press.

Paganelli, Maria Pia. 2003. In Medio Stat Virtus: An Alternative view of Usury in Adam Smith's Thinking. History of Political Economy 35.1:21-48.

Panico, Carlo. 2001. Monetary analysis in Sraffa's writings in Cozzi T, Marchionatti R. (ed.) Piero Sraffa's Political Economy. London: Routledge.

Pereire, Jacob Emile. 1832. Leçons sur l'industrie et les Finances prononcées à la salle de l'Athénée par J. Pereire, suivies d'un projet de banque. Paris: Bureau du Globe. (3rd and 4th lessons translated in English in Jacoud (2010), chap. 16-17-18).

Pereire, Jacob Emile, and Pereire, Isaac. [1834] 1866. Du système des banques et du système de Law. Paris: Paul Dupont.

Persky, Joseph. 2007. From Usury to Interest. Journal of Economic Perspectives. 21.1:227-36.

Pesciarelli, Enzo. 1989. Smith, Bentham, and the development of contrasting ideas on entrepreneurship. HOPE 21.3:521-696.

Picon, Antoine. 2002. Les saint-simoniens. Raison, imaginaire et utopie. Paris: Belin.

Pinto, Isaac de. 1771. Traité de la circulation et du crédit. Contenant une analyse raisonnée des fonds d'Angleterre. Amsterdam: Marc Michel Rey.

Reybaud, Louis. 1843. Etudes sur les réformateurs contemporains, ou socialistes modernes. Paris: Guillaumin et Cie.

Ricardo, David. [1817] 1819. On the Principles of Political Economy and Taxation, French translation, Des principes de l'économie politique et de l'impôt, traduit de l'anglais par Costancio F.S., avec des notes explicatives et critiques par M. Jean-Baptiste Say. Paris: Aillaud.

Rodrigues, Olinde 1825a. De l'industrie. Considérations générales sur les banquiers in Opinions littéraires, philosophiques et industrielles by Dr Bailly, Jean-Baptiste Duvergier, Léon Halévy, Olinde Rodrigues and Henri Saint-Simon. Paris: Bossange Père.

Rodrigues, Olinde 1825b. Considérations générales sur l'industrie (deuxième article). Le Producteur I. 5:193199, translated in English in Jacoud (2010), chap. 19.

-----. 1826a. Considérations sur le système de Law. Le Producteur IV.1:5-19.

----- 1826b. Law et son système de finances, par M. Thiers. Le Producteur IV.1:129-133.

----- 1831. De l'Industrie. Considérations générales sur les banquiers. Observations préliminaires. Le Globe, journal de la religion saint-simonienne, 7,327. Nov. 23 ${ }^{\text {rd }}, 1305-1306$; De l'industrie (IIème article). De l'état actuel des banquiers en Europe, idem, 7,328. Nov. $24^{\text {th }}: 1309-1310$.

Rouen P.-I. 1826. De la classe ouvrière. Deuxième article. Le Producteur IV.2:92-316.

Saint-Simon, Henri de. 1817. L'industrie ou Discussions politiques, morales et philosophiques dans l'intérêt de tous les hommes livrés à des travaux utiles et indépendants, in Oeuvres de Claude-Henri de Saint-Simon, [1875] 1966. Tome II. Paris: Anthropos.

Say, Jean.-Baptiste. 1817. Review of « Bentham's Plan of Parliamentary Reform ». Le censeur européen 5:105127.

-----. [1803] 2006. Traité d'économie politique, ou simple exposition de la manière dont se forment, se distribuent, et se consomment les richesses. In Euvres complètes I edited by E. Blanc, P.-H. Goutte, G. Jacoud, C. Mouchot, J.-P. Potier, M. Saquin, J.-M. Servet, P. Steiner, and A. Tiran (coord.). Paris: Economica.

Sigot, Nathalie. 1998. Les principes d'un système monétaire sain selon Bentham. Cahiers d'économie politique. 32:117-140.

Stark, William. 1952. Jeremy Bentham's Economic Writings. Critical Edition based on his printed works and unprinted manuscripts. Vol. I. London/New York: Routledge.

Staum, Martin S. 1998. French Lecturers in Political Economy, 1815-1848:Varieties of Liberalism. HOPE 30.1: 95-120.

Sraffa, Piero. 1929. Lectures on continental banking. Papers of Piero Sraffa (1898-1983), economist. Trinity College Library, Cambridge (via P. Garegnani). 
Storch, Henri. 1823. Cours d'économie politique ou Exposition des principes qui déterminent la prospérité des nations. Aves des notes explicatives et critiques par J.-B. Say. Tome II. Paris: Aillaud, Bossange, Rey and Gravier.

1824. Considérations sur la nature du revenu national. Paris: Bossange Père.

Thiers, Adolphe. 1826. Law et son système de finances. Paris: Bureau de 1'Encyclopédie Progressive. English transl. in 1859. John Law and the Mississippi Bubble, France 1719-1720. New-York: Townsend \& Co.

Tiran, André. 2003. Théorie du système monétaire chez Jean-Baptiste Say, in Jean-Baptiste Say. Nouveaux regards sur son æeuvre directed by J.-P. Potier, Tiran A. Paris: Economica.

Transon, Abel. 1831. Morale du monde, Le Globe. March $7^{\text {th }}$.

Turgot, Anne Robert J. [1769] 1828. Mémoire sur les prêts d'argent, in Défense de l'usure, ou Lettres sur les inconvénients des lois, qui fixent le taux de l'intérêt de l'argent, par Jérémy Bentham, traduit de l'anglais sur la 4è edition, suivi d'un mémoire sur les prêt d'argent, par Turgot. Paris: Malher et Compagnie.

Weill, Georges. 1896. L'école saint-simonienne, son histoire et son influence jusqu'à nos jours. Paris: Alcan.

Whatmore, Richard. 2007. Etienne Dumont, The British Constitution, and the French Revolution, Historical Journal 50.1:23-47. 